\title{
EKSPERIMENTASI KECERDASAN EMOSIONAL SISWA TERHADAP PEMBELAJARAN BAHASA INDONESIA OLEH SISWA KELAS VIII SMP TALITAKUM TAHUN PELAJARAN 2018/2019
}

\author{
Greis Hopina Siregar, Sariati Marpaung, Oktaviandi Bertua Pardede \\ Ayu Dini Kurnia, Yeni Charery Butar-butar \\ Program Studi Pendidikan Bahasa dan Sastra Indonesia \\ Fakultas Keguruan dan Ilmu Pendidikan Universitas Prima Indonesia \\ Email: Gracehop1703@gmail.com, Sariatimarpaung998@gmail.com, Ayudinikurnia1998@gmail.com, \\ yenibutar@gmail.com, andiepard21@gmail.com
}

\begin{abstract}
Abstrak
Pendekatan yang di lakukan guru dalam proses belajar mengajar sangat penting karena pendekatan tersebut dapat berdampak positif atau negatif terhadap hasil belajar siswa di kelas. Penelitian ini bertujuan untuk mengetahui bagaimana aktifitas, perbedaan hasil belajar dan respon siswa sebelum dan sesudah di lakukan pendekatan kecerdasan emsional kepada siswa di SMP Swasta Talitakum Medan. Jenis penelitian yang digunakan adalah penelitian eksperimen dengan menggunakan bentuk Pre Experimental Design dengan tipe the one goup pretest-posttest design. Pengumpulan data menggunakan, tes tertulis yang terdiri dari pre-test dan post-test, soal kecerdasan emosional dan angket. Aktivitas siswa diperoleh dari hasil pengamatan peneliti yaitu di peroleh perbandingan yaitu kelas yang di berikan pendekatan kercerdasan emosioal maka dapat di kategorikan sangat baik dalam merespon dan aktif dalam pembelaajran. Hal ini dikarenakan pendekatan kecerdasan emosional ini meberikan dampak yang positif terhadap diri siswa dimana siswa menjadi termotivasi da lebih bersemangat dalam belajar. Sedangkan pada kelas yang tidak di berikan pendekatan kecerdasan emosional dapat di katakan kurang memuaskan hasil yang di dapatkan karena masih di sebagain siswa yang memiliki motivas dan semangat belajar di kelas sehingga membuat kurangnya hasil pembelajaran bahasa indonesia yang di dapatkan

Data tes hasil belajar siswa dianalisis dengan di lakukan dua bentuk uji hipotesis yaitu hipotesis asosiatif dan hipotesis komparatif. Dan hasil yang diperoleh dalam uji hipotesis asosiatif adalah sebagai berikut Berdasarkan pengolahan SPSS maka harga sig. lebih kecil daripada harga $\alpha$ yaitu $0,001<0,05$. Dengan demikian diterima $\mathrm{H}_{\mathrm{a}}$ bahwa terdapat pengaruh yang signifikan kecerdasan emosional terhadap pembelajaran Bahasa Indonesia. Dan untuk mengetahui besarnya sumbangan efektif kecerdasan emosional dalam pembelajaran Bahasa Indonesia dapat digunakan hasil pengolahan SPSS melalui koefesien determinasi $\left(\mathrm{R}^{2}\right)$. Melalui hasil pengolahan pada tabel 3.6. diperoleh $\mathrm{R}^{2}$ sebesar 0,408 . Hal ini mengartikan bahwa kecerdasan emosional siswa memberikan sumbangan efektif sebesar 40,8\% berpengaruh terhadap pembelajaran Bahasa Indonesia siswa. Sedangkan sisanya 59,2\% dipengaruhi variabel lainnya yang tidak dianalisis dalam penelitian ini. Dan juga hasil uji hipotesis yang di peroleh dengan uji hopitesis komparatif adalah sebagai berikut dengan uji $t$ - paired sample test diperoleh sig lebih kecil dari pada $\alpha$ yaitu $0,000<$ 0,05 . Hal ini menunjukkan bahwa hasil belajar bahasa Indonesia oleh siswa mengalami perubahan yang signifikan (berarti).Dengan demikian dapat disimpulkan bahwa terdapat peningkatan hasil belajar siswa akibat pengaruh kecerdasan emosional yang distimulus kepada siswa melalui penelitian ini.
\end{abstract}

Kata Kunci : pengaruh kecerdasa emosional , Hasil belajar bahasa indonesia

\begin{abstract}
The teacher's approach is particularly important because it can have a positive and negative effect on the students learning in the class. It aims to know the scope of activity, the difference in the results of learning and responses before and after an approach an emotional intelligence to a student at the private junior Talitakum Medan. The kind of research used is experiental research by using pre-experimental design with the one goub pretest-postest design. Data collection uses a pre-test and post-test test, both for emotional intelligence and numerical intelligence. The student activity is based on the results of a researcher's observation that the comparison is given to a class that approaches emotional intelligence it is therefore highly classified in responses and very active in learning. It's in the wake of an approach of emotional intelligence damming a positive impact ona student being motivated and more spirited in learning. Be nice to a class where an unttainable approach to emotional intelligence can be said to be less gratifying as the result is still being for the most motivated and zealous students in the class, the understudy of the indonesian language has been achieved. Student learning outcomes test data were analyzed by doing two forms of hypothesis testing namely associative hypothesis and comparative hypothesis. And the result in the investigation of an associative hypothesis are as follows in the treatment of the SPSS. The price is smalla that $0,001<0.05$. thus accepted that there is a significant efect of emotional intelligence on indonesian learning.
\end{abstract}


And to know the enormous contribution of efektive emotional intelligence for indonesia learning in can be used the spss processing result. Throught the coefficient of determination $\left(R^{2}\right)$ throught the result of processing in table $3.6\left(R^{2}\right)$ is obtained by 0,408. this means the emotional complexity of students contributes effectively as much 40,8 as infivencing students'indnesian language learning. while the rest $59,2 \%$ influenced by other variables not analyzed in this study and also the result of learning by comparing the slide test result in a sig is smaller than $\alpha 0,000<0,05$. this shows that the result of learning indonesian by students experienced significant changes (meaning).such a study can be deduced that there ia an increases in the students' learning result from the effects of emotional in intelegence that is stimulus to the student undergraduate this study.

Keyword: emotional in intelegence

\section{PENDAHULUAN}

Kecerdasan emosional merupakan kemampuan seseorang untuk menilai dan memotivasi dirinya sendiri dan juga orang lain, dan kemampuan mengelola emosi dengan baik pada diri sendiri dalam hubungan dengan orang lain. Kemampuan ini dapat berkembang jika diterapkan secara kontiniu. Sehingga perlu diketahui fungsi manfaatnya terkait pembelajaran yang dilaksanakan di sekolah. Kecerdasan emosional secara nyata memberikan pengaruh yang cukup berarti dalam membina moral dan sikap peserta didik, dan tentunya juga akan memberikan dampak kepada kemampuan setiap peserta didik dalam menerima pembelajaran. Keterampilan dasar dalam menerapkan kecerdasan emosional tidak dapat dimiliki secara tiba-tiba, dibutuhkan proses dalam mempelajarinya serta lingkungan yang tepat untuk membentuk kecerdasan emosional yang optimal.

Terdapat beberapa cara yang dapat dilakukan untuk mengembangkan kecerdasan emosional dalam pembelajaran diantaranya: (1) menyediakan lingkungan yang kondusif; (2) menciptakan iklim pembelajaran yang demokratis; (3) mengembangkan sikap empati, dan merasakan apa yang sedang dirasakan peserta didik; (4) membantu peserta didik menemukan solusi dalam setiap masalah yang dihadapinya; (5) melibatkan peserta didik secara optimal dalam pembelajaran, baik secara fisik, sosial, maupun emosional; (6) merespon setiap perilaku peserta didik secara positif, dan menghindari respon negatif; (7) menjadi teladan dalam menegakkan aturan dan disiplin dalam pembelajaran; dan (8) memberi kebebasan berfikir kreatif serta partisipasi secara aktif. (Goleman, D., 2006:44).

Demikian juga menurut Muhyidin, M. (2007:47) bahwa kecerdasan emosional dapat membentuk siswa menjadi:

(1) jujur, disiplin, dan tulus pada diri sendiri, membangun kekuatan dan kesadaran diri, mendengarkan suara hati, hormat dan tanggung jawab; (2) memantapkan diri, maju terus, ulet, dan membangun inspirasi secara berkesinambungan; (3) membangun watak dan kewibawaan, meningkatkan potensi, dan mengintegrasi tujuan belajar ke dalam tujuan hidupnya; (4) memanfaatkan peluang dan menciptakan masa depan yang lebih cerah".

Pendidikan bahasa Indonesia adalah salah satu disiplin ilmu yang sangat penting untuk diajarkan kepada setiap siswa di sekolah. Seperti diketahui bersama bahwa pembelajaran bahasa Indonesia ini sudah diajarkan sejak siswa di bangku Sekolah Dasar (SD). Dalam bahasa Indonesia siswa sudah harus dapat memahami dan menerapkan keterampilan berbahasa seperti membaca,menyimak, menulis dan berbicara. Dan seluruh hasil belajar tersebut dapat diperoleh jika penerapan pembelajaran bahasa Indonesia diterapkan dengan baik dan benar.

Dalam pembelajaran di beberapa sekolah terdapat siswa yang tidak dapat meraih hasil belajar yang setara dengan kemampuan intelegensinya. Artinya terdapat siswa yang memiliki intelegensi yang rendah tetapi masih dapat meraih hasil belajar yang relatif tinggi. Itulah sebabnya mengapa taraf intelegensi bukan merupakan satu-satunya faktor yang menentukan keberhasilan seorang karena diyakini masih terdapat faktor lain yang mempengaruhi. Sehingga dalam penelitian ini diharapkan keberadaan aspek kecerdasan emosional dapat dijadikan faktor lainnya yang dimaksud.

Intelegensi Quotient (IQ) atau keceradasan intelektual hanya menyumbang $20 \%$ bagi prestasi belajar,sedangkan $80 \%$ sisanya merupakan sumbangan faktor kekuatan-kekuatan lainnya salah satunya adalah faktor kecerdasan emosional atau Emotional Quotient(EQ) yang merupakan kemampuan mengenal diri sendiri,mengatasifrustasi,mengontrol desakan hati, mengatur suasana hati (mood) serta kemampuan bekerja sama (Goleman, 2000:44).

Setiap siswa memiliki karakter yang unik dan berbeda-beda, hal ini dapat diperhatikan melalui cara mereka bergaul,belajar di kelas dan juga sikap terhadap lingkungan di sekitarnya. Artinya terdapat keberagaman siswa dalam mengenali dan memahami emosinya sendiri sehingga kemampuan untuk mengontrol emosinya dapat ditentukan melalui kecerdasan emosional siswa itu sendiri. Misalnya ketika siswa sedang malas belajar atau sedang memiliki permasalahan maka tidak dipungkiri sikap belajar yang ditunjukkan oleh siswa mengarah pada hal yang negatif, seperti bolos atau bercanda saat guru menerangkan. 
Mengingat bahwa kecerdasan emosional yang dimiliki siswa sangat berpengaruh terhadap hasil belajar, maka perlunya tindakan guru untuk memancing emosi siswa dalam pembelajaran. Guru dapat memberikan treatment berupa sugesti atau motivasi baik dalam bentuk stimulus maupun apersepsi sehingga menimbulkan reaksi dari siswa untuk berupaya membenarkan dirinya untuk belajar sungguh-sungguh dan berupaya menguasai dengan serius pelajaran bahasa Indonesia selayaknya mata pelajaran matematika atau IPA.

Berdasarkan uraian di atas tim tertarik untuk membuktikan ekfektivitas kecerdasan emosional pada mata pelajaran bahasa Indonesia di SMP Talitakum Medan. Melalui sederetan upaya (wawancara dan observasi) yang telah dilakukan tim peneliti dapat diidentifikasikan dan didiagnosis bahwa hasil belajar siswa di SMP ini baik, dimana pada tiap kenaikan kelas sangat jarang ditemukan siswa yang tinggal kelas. Namun peneliti menemukan hasil belajar beberapa mata pelajaran tidak ekuivalensi. Artinya rata-rata hasil belajar siswa setiap mata pelajaran tidak sebanding dengan tingkat kesulitan setiap mata pelajaran. Terutama pada mata pelajaran bahasa Indonesia dengan mata pelajaran sains (Matematikan, dan IPA) tampak bahwa rata-rata hasil belajarnya tidak berbeda jauh satu sama lain, bahkan variasi nilai di atas KKM (Kriteria Ketuntasan Minimum) bahasa Indonesia lebih kecil dibandingkan dengan mata pelajaran sains. Padahal tingkat kesulitan bahasa Indonesia tidak sekompleks mata pelajaran sains tersebut. Oleh karena itu, peneliti akan mengekplorasi kecerdasaan emosional siswa dengan harapan variabel ini dapat membuktikan pengaruhnya terhadap hasil belajar siswa dalam pelajaran bahasa Indonesia.

Sesuai dengan paradigma yang telah diurai, maka peneliti akan mengadakan eksperimentasi kecerdasan emosional siswa terhadap pembelajaran bahasa Indonesia oleh siswa kelas VIII di SMP Talitakum Medan Tahun Pelajaran 2018/2019. Berdasarkan latar belakang masalah-masalah yang teridentifikasi antara lain sebagai berikut :

1. kecerdasan emosional belum diutamakan sebagai indikator pencapaian prestasi belajar siswa.

2. rendahnya motivasi dan sikap belajar dalam pembelajaran bahasa Indonesia

3. kurangnya perhatian guru terhadap perkembangan kecerdasan emosional siswa dalam pembelajaran.

4. kurangnya kesadaran diri siswa terhadap pentingnya pembelajaran di sekolah terutama pembelajaran bahasa indonesia.

\section{METODE PENELITIAN}

Populasi penelitian ini adalah siswa SMP Talitakum Medan. Adapun data siswa yang dimaksud adalah kelas VII, VIII dan IX dengan jumlah keseluruhan 86 siswa. Berdasarkan data siswa tersebut maka jumlah sampel akan direduksi melalui teknik penarikan sampel dengan cara purposivesampling. Teknik penarikan sampel ini digunakan oleh karena pertimbangan jumlah peserta didik yang kurang dari 100 orang dan hanya memiliki masing-masing kelas dalam stratanya. Oleh karena itu dengan teknik dipilihlah kelas VIII sebagai sampel dalam penelitian.

a. Variabel Penelitian

Variabel bebas dalam penelitian ini adalah dengan kecerdasan emosional. Sedangkan variabel terikat dalam penelitian ini adalah hasil belajar siswa dalam pembelajaran bahasa Indonesia.

b. Jenis dan Desain Penelitian

Jenis pendekatan penelitian yang digunakan dalam penelitian ini adalah pendekatan kuantitatif. Sesuai dengan paradigma rumusan masalah yaitu deskriptif dan asosiatif maka variabel penelitian ini akan ditelaah hubungannnya dan akan disajikan gambaran secara terstruktur dan faktual terkait fakta-fakta serta hubungan antara variabel yang diteliti.

Adapun metode penelitian yang diterapkan dalam penelitian ini adalah metode eksperimen dengan menggunakan bentuk Pre Experimental Design dengan tipe the one goup pretest-posttest design. Sesuai dengan paradigma yang dihasilkan pada rumusan tujuan penelitian maka alat pengumpul data (instrumen) yang digunakan dalam penelitian ini terdiri atas dua bentuk yaitu tes dan nontes. Pada variabel hasil belajar bahasa Indonesia siswa tes terdiri atas 20 soal pilihan ganda. Sedangkan pada variabel kecerdasan emosional tes disusun sebanyak 10 soal pilihan ganda.

Selanjutnya nontes digunakan untuk mengetahui psikologis kecerdasan emosional siswa, dan nontes ini disusun dalam bentuk angket sebanyak 20 butir pernyataan tentang kecerdasan emosional. Sebelum instrumen tersebut digunakan sebagai alat pengumpul data terlebih dahulu divalidasi oleh validator/ para ahli yang bertujuan untuk mengetahui kelayakan instrumen. Berikut ini kisi-kisi instrumen variabel hasil belajar bahasa Indonesia:

Tabel 2.1. Kisi-kisi Instrumen Hasil Belajar Bahasa Indonesia 


\begin{tabular}{|c|c|c|c|c|c|c|c|c|}
\hline \multirow{2}{*}{ No } & \multirow{2}{*}{ Sub unsur materi } & \multicolumn{6}{|c|}{ Ranah kognitif/nomor soal } & \multirow{2}{*}{$\sum$} \\
\hline & & C1 & $\mathrm{C2}$ & $\mathbf{C 3}$ & C4 & $\mathbf{C 5}$ & C6 & \\
\hline 1 & Teks wacana & 1 & 2 & 5 & 3 & - & - & 4 \\
\hline 2 & Teks pernyataan dan cerpen & 4 & - & - & 6 & 7 & 16 & 4 \\
\hline 3 & Puisi dan diskusi & 18 & 19 & - & 8,10 & 17 & 20 & 6 \\
\hline 4 & Slogan Dan Poster & - & - & 15 & 14 & - & & 2 \\
\hline 5 & $\begin{array}{l}\text { Kata baku dan pembawa } \\
\text { acara }\end{array}$ & 12 & 11 & - & 13 & - & 9 & 4 \\
\hline \multicolumn{8}{|c|}{ Jumlah } & 20 \\
\hline
\end{tabular}

Keterangan:

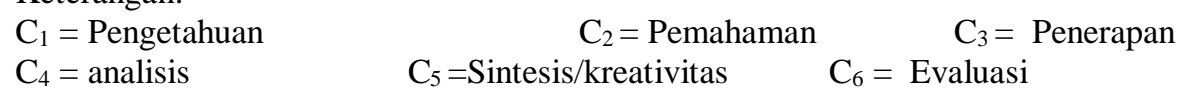

Selanjutnya untuk instrumen variabel kecerdasan emosional akan diberlakukan dua bentuk yaitu soal pilihan ganda dan soal angket. Skala pengukuran masing-masing bentuk soal adalah skala interval dan skala ordinal. Adapun kisi-kisi instrumen variabel kecerdasan emosional yang akan digunakan dapat diperhatikan pada tabel berikut ini:

Tabel 2.2. Kisi-kisi Instrumen Kecerdasan Emosional

\begin{tabular}{|l|l|l|}
\hline No & Aspek & Nomor Pernyataan \\
\hline 1 & Kesadaran diri & 1,2 \\
\hline 2 & Mengelola emosi & 3,10 \\
\hline 3 & Optimisme & 7,8 \\
\hline 4 & Empati & 5,6 \\
\hline 5 & Keterampilan Sosial & 4,9 \\
\hline
\end{tabular}

Kriteria penilaian untuk setiap soal pilihan ganda yang dijawab benar akan diberi skor 1 dan salah akan diberi skor 0. Siswa akan menjawab pertanyaan soal sesuai dengan ketentuan dalam pilihan ganda. Sehingga pengukuran skor akan menghitung jumlah seluruh jawaban benar - salah siswa dan selanjutnya akan dinilai dengan rumus serta diklasifikasikan dengan acuan berikut ini :

Nilai $=\frac{\text { jumlah skor yang diperoleh }}{\text { jumlah skor total }} \times 100$

Tabel 2.3. Kategori Penilaian Instrumen Tes (Pilihan Ganda)

\begin{tabular}{|l|l|}
\hline Interval & Kriteria \\
\hline $80-100$ & Baik sekali \\
\hline $60-79$ & Baik \\
\hline $40-59$ & Cukup \\
\hline $30-49$ & Kurang \\
\hline $0-29$ & Gagal \\
\hline
\end{tabular}

Sedangkan untuk instrumen nontes akan menggunakan acuan penskoran skala likert yaitu skala yang digunakan untuk mengukur sikap, pendapat, dan persepsi seseorang atau kelompok tentang fenomena sosial (Sugiyono, 2009: 134). Indikator variabel yang dimuat dalam pernyataan akan dijawab oleh siswa dengan memberikan tanda " ل" pada pilihan sangat setuju, setuju, netral, kurang setuju, tidak setuju. Berikut ini alternatif jawaban untuk tiap butir beserta skor untuk pernyataan favorable dan unfavorable yang disajikan pada tabel 6

Tabel 2.4. Kategori Penilaian Instrumen Nontes (Angket)

\begin{tabular}{|l|l|l|}
\hline \multirow{2}{*}{ Alternatif Jawaban } & \multicolumn{2}{|l|}{ Skor untuk Pernyataan } \\
\cline { 2 - 3 } & Favorable & unfavorable \\
\hline Sangat Setuju & 5 & 1 \\
\hline Setuju & 4 & 2 \\
\hline Netral & 3 & 3 \\
\hline Kurang Setuju & 2 & 4 \\
\hline Tidak Setuju & 1 & 5 \\
\hline
\end{tabular}

Adapun acuan rentang skor angket yang diperoleh akan disesuaikan dengan hasil telaah para ahli, dan berikut gambaran rentang skor yang akan digunakan: 


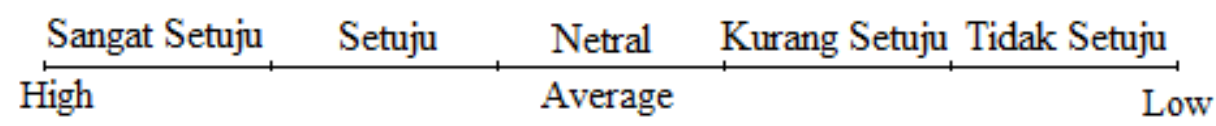

c. Teknik Analisis Data

Teknik analisis data yang digunakan adalah teknik statistik deskriptif dan inferensial. Teknik statistik deskriptif digunakan untuk mendeskripsikan data, antara lain nilai rata-rata (mean), varians dan simpangan baku. Dan teknik statistik inferensial digunakan untuk menguji hipotesis penelitian. Teknik inferensial yang akan digunakan dalam penelitian ini adalah analisis regresi tunggal (linier) dan uji t. Penerapan analisis regresi bertujuan untuk mengetahui besarnya pengaruh kecerdasan emosional siswa dalam pembelajaran. Oleh karena itu, sebelum menguji hipotesis penelitian maka terlebih dahulu akan dianalisis normalitas data dan linieritas data. Sedangkan penggunaan uji t bertujuan untuk mengetahui adanya perbedaan hasil belajar yang signifikan dari dua kondisi tes yang berbeda waktu pelaksanaannya dan akan dilakukan uji prasyarat yakni normalitas data. Selanjutnya analisis data dilanjutnkan dengan menentukan nilai rata-rata dan simpangan baku data, uji normalitas, uji linieritas dan uji Hipotesis.

\section{HASIL DAN PEMBAHASAN PENELITIAN}

Deskriptif data penelitian yang dilakukan dalam laporan hasil penelitian ini bertujuan memberikan gambaran tentang hasil aktivitas penelitian dan tujuan penelitian yang telah dicapai selama melakukan pengumpulan data. Perlu diketahui juga bahwa penelitian ini telah mengujicobakan instrumen penelitian melalui para ahli, sehingga hasil penelitian yang diperoleh memiliki signifikansi terhadap variabel yang diteliti. Untuk itu pada lampiran dapat dibuktikan uji kelayakan yang dilakukan dengan para ahli.

Subjek penelitian ini adalah siswa SMP Talitakum Medan dan melalui teknik pengambilan sampel diperoleh kelas VIII sebagai sampelnya (subjek penelitian). Selanjutnya berdasarkan hasil observasi diketahui banyak siswa yang mengalami belum menunjukkan tingkat emosional yang baik. Hal ini dapat diketahui dengan banyaknya aktivitas siswa yang cenderung mengacuhkan guru ketika belajar, kurangnya inisiatif sikap untuk menghargai aktivitas belajar yang telah dikondisikan oleh guru, serta motivasi yang diberikan oleh guru belum signifikan dalam membentuk kesadaran siswa untuk berprestasi dalam belajar. Sehingga eksperimentasi yang dilakukan memperhatikan perihal ini. Oleh karena itu selanjutnya akan diuraikan hasil eksperimentasi penelitian.

a. Hasil Tes Bahasa Indonesia Siswa

Hasil belajar yang diperoleh dalam penelitian ini merupakan evaluasi yang dilakukan oleh peneliti melalui instrumen tes dengan materi pelajaran yang sudah dibelajarkan sebelumnya. Tujuan dilakukan tes adalah untuk memahami kemampuan belajar siswa sekaligus menggunakan data ini untuk kemudian dikaitkan terhadap hasil analisis kecerdasan emosional siswa. Berikut ini adalah hasil belajar yang telah diperoleh dalam penelitian:

Tabel 3.1. Hasil Tes Bahasa Indonesia

\begin{tabular}{|l|l|l|}
\hline Rentang Nilai & Pretes & Postes \\
\hline $80-100$ & $2(8 \%)$ & $4(16 \%)$ \\
\hline $60-79$ & $13(52 \%)$ & $21(84 \%)$ \\
\hline $40-59$ & $10(40 \%)$ & $0(0 \%)$ \\
\hline $30-49$ & $0(0 \%)$ & $0(0 \%)$ \\
\hline $0-29$ & $0(0 \%)$ & $0(0 \%)$ \\
\hline
\end{tabular}

Berdasarkan tabel 3.1. dapat dideskripsikan bahwa kemampuan awal siswa dalam pelajaran bahasa Indonesia masih belum memenuhi target (memenuhi KKM yang ditentukan di sekolah). Sehingga melalui pembelajaran dengan menguatkan kecerdasan emosional siswa maka kemampuan akhir siswa berbeda dari kondisi sebelum ditreatmen. Dan berikut ini beberapa parameter yang digunakan untuk menggambarkan kemampuan bahasa Indonesia siswa

Table 3.2. Deskriptif Hasil Tes

\begin{tabular}{|l|l|l|l|}
\hline \multicolumn{2}{|l|}{ Pretes-psotes } & Statistic \\
\hline \multirow{4}{*}{$\begin{array}{l}\text { Hasil Tes } \\
\text { Bahasa } \\
\text { Indonesia }\end{array}$} & \multirow{4}{*}{ Pretes } & Mean & 61,4400 \\
\cline { 3 - 4 } & & Vedian & 63,0000 \\
\cline { 3 - 4 } & & Std. Deviation & 148,173 \\
\cline { 3 - 4 } & & Minimum & 12,17265 \\
\cline { 3 - 4 } & Maximum & 43,00 \\
\cline { 3 - 4 } & Postes & Mean & 93,00 \\
\hline
\end{tabular}




\begin{tabular}{|l|l|}
\hline Median & 75,0000 \\
\hline Variance & 48,710 \\
\hline Std. Deviation & 6,97925 \\
\hline Minimum & 60,00 \\
\hline Maximum & 90,00 \\
\hline
\end{tabular}

Tampak bahwa rata-rata (mean) pretes berbeda dengan mean postes, hasil tes ini juga menggambarkan bahwa data pretes lebih bervariasi daripada data postes dengan penyimpangan data terbesar terdapat juga pada data pretes. Dari tabel 3.2 dapat juga diketahui bahwa masing-masing nilai terendah dan tertinggi untuk setiap populasi data yaitu 40/80 dan 65/88. Dengan demikian data ini dapat dijadikan indikator untuk uji persyaratan selanjutnya. Namun terlebih dahulu untuk deskriptif data perlu digambarkan histogram data hasil tes penelitian ini, dan berikut gambarnya:

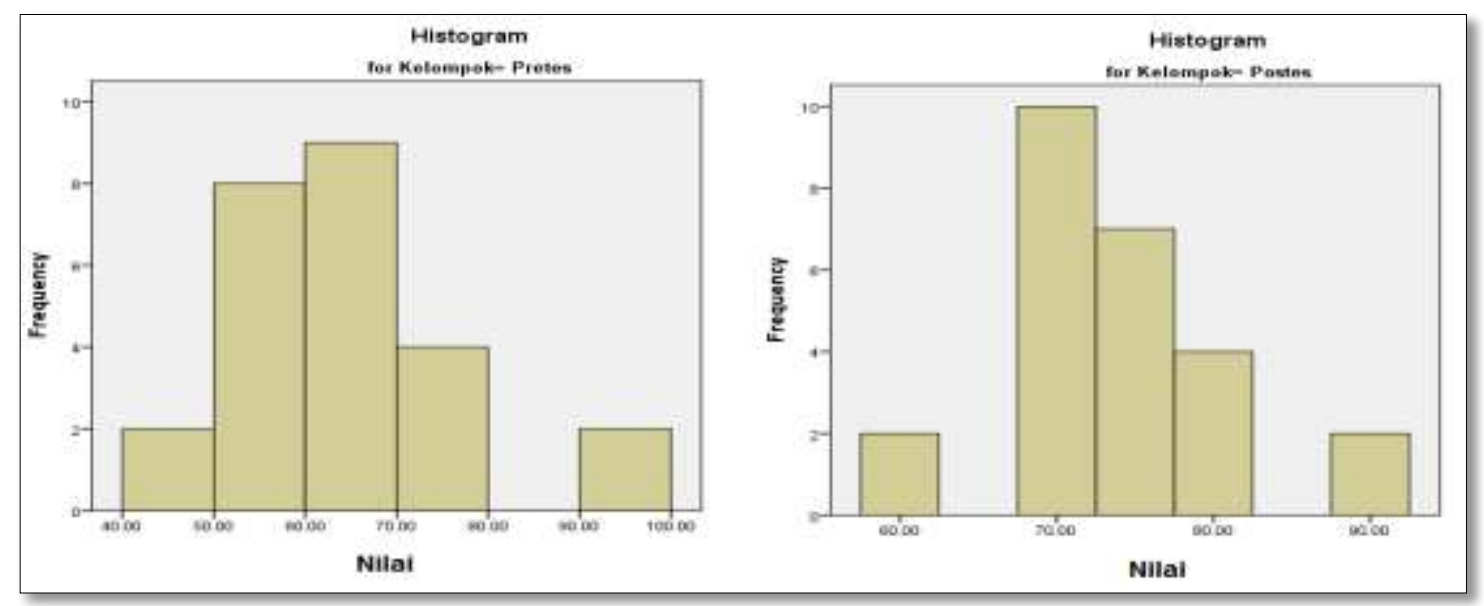

Gambar 3.1. Histogram data pretes dan postes

b. Hasil Tes dan nontes Kecerdasan Emosional

Bentuk tes kecerdasan emosional penelitian ini memperhatikan komposisi kesesuaian usia atau umur peserta didik, sehingga butir angket yang digunakan hanya mencakup 5 unsur kecerdasan emosional yang telah diuraikan dalam sub bab alat dan pengumpul data. Berikut ini adalah deskripsi data kecerdasan emosional:

Table 3.3. Hasil Tes dan Angket Kecerdasan Emosional

\begin{tabular}{|c|c|c|c|c|c|c|c|}
\hline \multirow[t]{2}{*}{ Nama } & \multirow{2}{*}{$\begin{array}{l}\text { Nilai Hasil } \\
\text { Tes }\end{array}$} & \multicolumn{6}{|c|}{ Angket (persentase memilih) } \\
\hline & & Butir Soal & SS & $\mathrm{S}$ & $\mathrm{N}$ & KS & TS \\
\hline AGNES & 120 & 1 & $56 \%$ & $20 \%$ & $8 \%$ & $12 \%$ & $4 \%$ \\
\hline ALOAN & 120 & 2 & $24 \%$ & $44 \%$ & $12 \%$ & $24 \%$ & $0 \%$ \\
\hline AGUS & 85 & 3 & $0 \%$ & $8 \%$ & $12 \%$ & $40 \%$ & $40 \%$ \\
\hline CECILIA & 135 & 4 & $4 \%$ & $40 \%$ & $32 \%$ & $12 \%$ & $12 \%$ \\
\hline DANIEL & 82 & 5 & $20 \%$ & $36 \%$ & $8 \%$ & $24 \%$ & $12 \%$ \\
\hline FEBRIANI & 85 & 6 & $12 \%$ & $20 \%$ & $12 \%$ & $28 \%$ & $28 \%$ \\
\hline GABRIEL & 165 & 7 & $36 \%$ & $24 \%$ & $20 \%$ & $12 \%$ & $8 \%$ \\
\hline HENDRA & 135 & 8 & $28 \%$ & $40 \%$ & $16 \%$ & $16 \%$ & $0 \%$ \\
\hline HORAS & 110 & 9 & $32 \%$ & $44 \%$ & $8 \%$ & $12 \%$ & $4 \%$ \\
\hline IMANUEL & 60 & 10 & $0 \%$ & $36 \%$ & $28 \%$ & $28 \%$ & $8 \%$ \\
\hline IRFANSYAH & 105 & 11 & $44 \%$ & $16 \%$ & $20 \%$ & $20 \%$ & $0 \%$ \\
\hline JERY & 165 & 12 & $28 \%$ & $20 \%$ & $28 \%$ & $16 \%$ & $8 \%$ \\
\hline JENIUS & 80 & 13 & $48 \%$ & $28 \%$ & $16 \%$ & $8 \%$ & $0 \%$ \\
\hline KEVIN & 155 & 14 & $20 \%$ & $56 \%$ & $12 \%$ & $12 \%$ & $0 \%$ \\
\hline OTOLIUS & 135 & 15 & $36 \%$ & $24 \%$ & $4 \%$ & $16 \%$ & $20 \%$ \\
\hline MELANI & 50 & 16 & $68 \%$ & $28 \%$ & $4 \%$ & $0 \%$ & $0 \%$ \\
\hline MARCEL & 120 & 17 & $28 \%$ & $36 \%$ & $20 \%$ & $16 \%$ & $0 \%$ \\
\hline NOVENA & 135 & 18 & $52 \%$ & $40 \%$ & $4 \%$ & $4 \%$ & $0 \%$ \\
\hline RIA & 135 & 19 & $48 \%$ & $32 \%$ & $8 \%$ & $8 \%$ & $4 \%$ \\
\hline RYAN & 135 & 20 & $48 \%$ & $32 \%$ & $8 \%$ & $8 \%$ & $4 \%$ \\
\hline RISAN & 76 & Rata-rata & $32 \%$ & $31 \%$ & $14 \%$ & $16 \%$ & $8 \%$ \\
\hline SOPHIA & 80 & & & & & & \\
\hline FRANSISCO & 120 & & & & & & \\
\hline
\end{tabular}




\begin{tabular}{|c|c|c|c|c|c|c|c|c|c|c|}
\hline & & \multicolumn{2}{|c|}{ Sangat Setuju } & \multicolumn{2}{|c|}{ Setuju } & \multirow{2}{*}{$\frac{\text { Netral }}{\text { Average }}$} & \multicolumn{2}{|c|}{ Kurang Setuju } & dak S & aju \\
\hline RIVANY & 100 & High & & & & & & & & Low \\
\hline $\begin{array}{l}\text { SHINTIA } \\
\text { Rata-rata }\end{array}$ & $\begin{array}{l}120 \\
112,32\end{array}$ & 200 & 175 & 150 & 125 & 100 & 75 & 50 & 25 & 0 \\
\hline
\end{tabular}

Berdasarkan tabel 3.3 dapat diketahui bahwa hasil tes dan angket kecerdasan emosional di atas menunjukkan rata-rata tes yaitu 112,32 sedangkan hasil angket diperoleh kecederungan pilihan pada sangat setuju dan setuju dengan masing - masing persentase sebesar 32\% dan 31\%. Dengan merujuk acuan kriteria penilaian yang telah dirumuskan maka untuk hasil tes kecerdasan emosional memiliki kecerdasan emosional yang baik karena memiliki rata-rata di atas 100 (ukuran rata-rata kecerdasan emosional). Selanjutnya untuk hasil angket dapat juga diketahui bahwa pilihan siswa cederung pada pilihan setuju dan sangat setuju, dan untuk angket pendeskripsiannya haruslah melalui tahap pengkonversian skala likert yaitu sebagai berikut

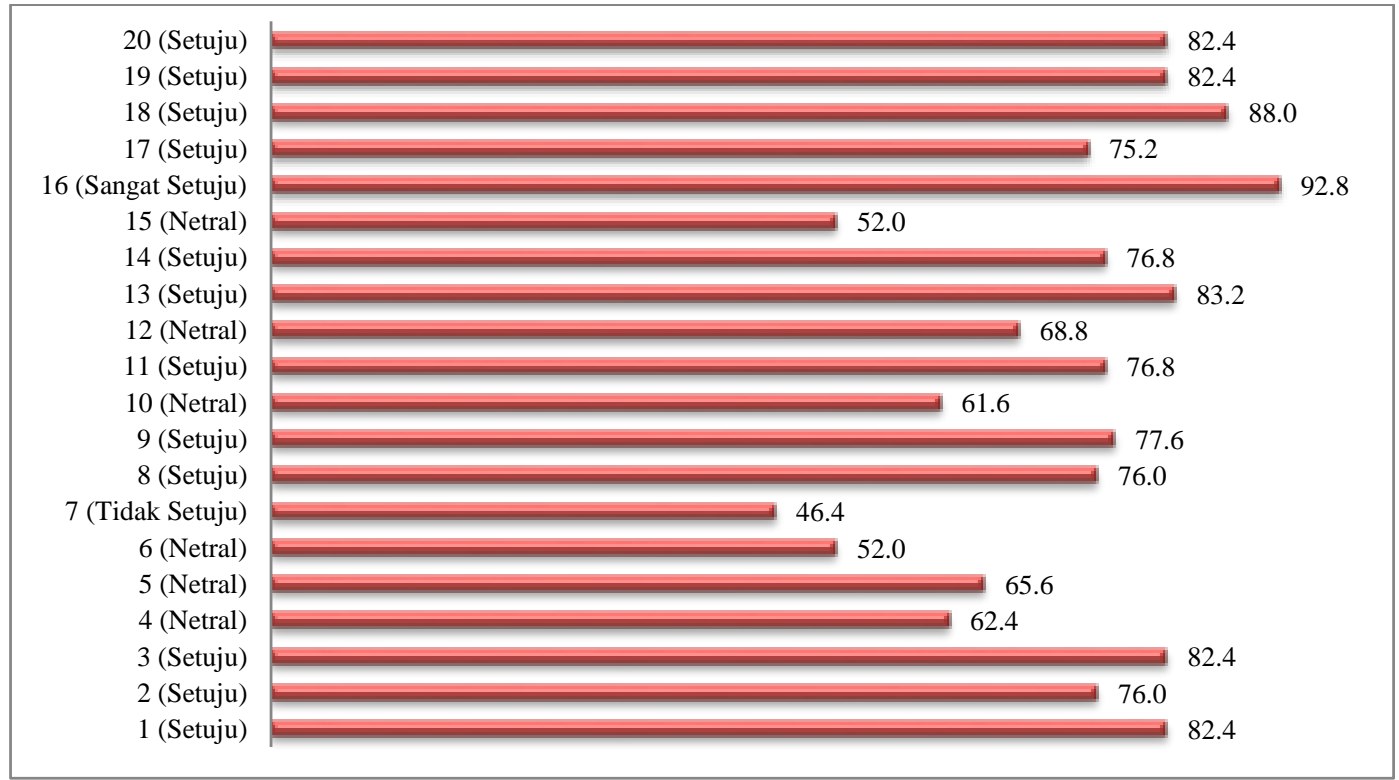

Gambar 3.2. Hasil konversi skala Likert

Berdasarkan gambar 3.2. di atas dapat diketahui bahwa dari 20 butir angket terdapat 5\% yang sangat setuju, $60 \%$ setuju, 30\% netral, dan 5\% tidak setuju. Dan ini menunjukkan bahwa untuk setiap butir instrumen kecerdasan emosional siswa cenderung.

\section{c. Uji Normalitas}

Uji normalitas digunakan untuk mengetahui kenormalan data yang diperoleh dari populasi penelitian. Dalam penelitian ini uji kenormalan dilakukan terhadap 3 data yaitu data pretes, postes dan kecerdasan emosional. Dengan menggunakan uji kolmogorov - smirnov yang diolah dengan menggunakan SPSS 23.0. maka diperoleh hasilnya sebagai berikut:

Tabel 3.4. Hasil Uji Normalitas data

\begin{tabular}{|l|l|l|l|l|}
\hline \multicolumn{2}{|l|}{ Kriteria Pengujian } & \multicolumn{3}{|l|}{ Kolmogorov-Smirnov } \\
\cline { 3 - 5 } \multicolumn{2}{|l|}{} & Statistic & Df & Sig. \\
\hline $\begin{array}{l}\text { Tes B } \\
\text { Indonesia }\end{array}$ & Pretes & .161 & 25 & .094 \\
\cline { 2 - 5 } $\begin{array}{l}\text { Nontes } \\
\text { (angket) }\end{array}$ & $\begin{array}{l}\text { Kecerdasan } \\
\text { Emosional }\end{array}$ & .147 & 25 & .170 \\
\hline
\end{tabular}

a. Lilliefors Significance Correction

Berdasarkan hasil analisis SPSS di atas maka ketiga data memperoleh kenormalan yang signifikan dengan besar sig $>\alpha$. Hal tersebut dibuktikan bahwa besar masing-masing harga sig 0,094;0,170;0,133 lebih besar dari 0,05 . Dengan demikian dapat $H_{0}$ diterima bahwa data yang berasal dari populasi yang berdistribusi normal.

d. Uji Linieritas 
Uji linearitas digunakan untuk mengetahui kelinearan hubungan variabel bebas terhadap variabel terikat. Melalui analisis varians (Anova) dengan menggunakan lajur deviation from linearity pada program SPSS 23.0 maka diperoleh hasil pengolahannya sebagai berikut

Tabel 3.5. Hasil Uji Linearitas (Anova Table)

\begin{tabular}{|c|c|c|c|c|c|c|c|}
\hline & & & $\begin{array}{l}\text { Sum of } \\
\text { Squares }\end{array}$ & df & $\begin{array}{l}\text { Mean } \\
\text { Square }\end{array}$ & $\mathrm{F}$ & Sig. \\
\hline \multirow{5}{*}{$\begin{array}{ll}\text { Bahasa } & \text { Indonesia } \\
\text { Kecerdasan } & \text { Emosional }\end{array}$} & \multirow{3}{*}{$\begin{array}{l}\text { * Between } \\
\text { Groups }\end{array}$} & (Combined) & 317.573 & 12 & 26.464 & 2.290 & .083 \\
\hline & & Linearity & 186.022 & 1 & 186.022 & 16.098 & .002 \\
\hline & & $\begin{array}{l}\text { Deviation from } \\
\text { Linearity }\end{array}$ & 131.551 & 11 & 11.959 & 1.035 & .474 \\
\hline & \multicolumn{2}{|c|}{ Within Groups } & 138.667 & 12 & 11.556 & & \\
\hline & \multicolumn{2}{|l|}{ Total } & 456.240 & 24 & & & \\
\hline
\end{tabular}

Berdasarkan hasil pengolahan SPSS pada tabel diatas maka diperoleh Sign adalah 0,474. berarti dalam hal ini Sign. lebih besar dari $\alpha(0,378>0,05)$. Sehingga dapat simpulkan bahwa antara gambaran kecerdasan emosional peserta didik dengan gambaran hasil belajar Bahasa Indonesia memiliki hubungan yang linear.

\section{e. Uji Hipotesis}

Setelah data dideskripsikan dan diujipersyaratkan selanjutnya dilakukan penyimpulan hasil penelitian melalui pengujian hipotesis. Dalam penelitian ini terdapat dua bentuk uji hipotesis yaitu hipotesis asosiatif dan hipotesis komparatif. Maka terlebih dahulu diuraikan hasil pengolahan analisis regresi yakni pengaruh kecerdasan emosional terhadap pembelajaran Bahasa Indonesia. Dari hasil uji hipotesis asosiatif ini dianalisis melalui analisis regresi. Dan untuk memperoleh ada atau tidaknya pengaruh kecerdasan emosional siswa terhadap pembelajaran bahasa Indonesia maka digunakan analisis taraf signifikansi melalui tabel anova.

Tabel 3.6. ANOVA ${ }^{\mathrm{a}}$

\begin{tabular}{|ll|l|l|l|l|l|}
\hline Model & & Sum of Squares & Df & Mean Square & F & Sig. \\
\hline 1 & Regression & 186.022 & 1 & 186.022 & 15.834 & $.001^{\mathrm{b}}$ \\
& Residual & 270.218 & 23 & 11.749 & & \\
& Total & 456.240 & 24 & & & \\
\hline
\end{tabular}

a. Dependent Variable: Bahasa Indonesia

b. Predictors: (Constant), Kecerdasan Emosional

Tabel 3.5. digunakan untuk mengetahui taraf signifikansi (model regresi yang digunakan) antara variabel bebas terhadap variabel terikat. Berdasarkan pengolahan SPSS maka harga sig. lebih kecil daripada harga $\alpha$ yaitu $0,001<0,05$. Dengan demikian diterima $\mathrm{H}_{\mathrm{a}}$ bahwa terdapat pengaruh yang signifikan kecerdasan emosional terhadap pembelajaran Bahasa Indonesia. Dan untuk mengetahui besarnya sumbangan efektif kecerdasan emosional dalam pembelajaran Bahasa Indonesia dapat digunakan hasil pengolahan SPSS melalui koefesien determinasi $\left(\mathrm{R}^{2}\right)$ yang terdapat pada tabel measure of association.

Tabel 3.7. Measures of Association

\begin{tabular}{|l|l|l|l|l|}
\hline & R & R Squared & Eta & Eta Squared \\
\hline $\begin{array}{l}\text { Bahasa Indonesia * Kecerdasan } \\
\text { Emosional }\end{array}$ & .639 & .408 & .834 & .696 \\
\hline
\end{tabular}

Melalui hasil pengolahan pada tabel 3.6. diperoleh $\mathrm{R}^{2}$ sebesar 0,408 . Hal ini mengartikan bahwa kecerdasan emosional siswa memberikan sumbangan efektif sebesar $40,8 \%$ berpengaruh terhadap pembelajaran Bahasa Indonesia siswa. Sedangkan sisanya 59,2\% dipengaruhi variabel lainnya yang tidak dianalisis dalam penelitian ini. Selanjutnya untuk mengetahui model regresi dapat digunakan untuk memprediksi pembelajaran bahasa Indonesia yang diberikan kepada siswa maka digunakan tabel coefficients berikut ini Tabel 3.8. Coefficients ${ }^{\mathrm{a}}$

\begin{tabular}{|c|c|c|c|c|c|}
\hline \multirow[b]{2}{*}{ Model } & \multicolumn{2}{|c|}{ Unstandardized Coefficients } & \multirow{2}{*}{$\begin{array}{l}\text { Standardized } \\
\text { Coefficients } \\
\text { Beta }\end{array}$} & \multirow[b]{2}{*}{$\mathrm{T}$} & \multirow[b]{2}{*}{ Sig. } \\
\hline & $\mathrm{B}$ & Std. Error & & & \\
\hline $\begin{array}{ll}1 & \text { (Constant) } \\
& \text { Kecerdasan Emosional }\end{array}$ & $\begin{array}{l}53.330 \\
.280\end{array}$ & $\begin{array}{l}5.110 \\
.070\end{array}$ & .639 & $\begin{array}{l}10.436 \\
3.979\end{array}$ & $\begin{array}{l}.000 \\
.001\end{array}$ \\
\hline
\end{tabular}

a. Dependent Variable: Bahasa Indonesia

Berdasarkan hasil pengolahan SPSS 23.0 di atas diperoleh sig lebih kecil dari $\alpha$ yaitu $0,001<0,05$. Dengan demikian dapat disimpulkan bahwa model regresi dapat digunakan dan berdasarkan hasil analisis diperoleh nilai beta $\left(\mathrm{B}_{2}\right)$ untuk variabel kecerdasan emosional siswa adalah 0,280 artinya nilai prediksi kecerdasan emosi terhadap pembelajaran bahasa Indonesia sebesar 0,623. Sehingga dapat disimpulkan bahwa pembelajaran bahasa Indonesia dipengaruhi oleh kecerdasan emosial siswa dengan persamaan 
regresi yang merujuk pada rumus: $\widehat{\mathrm{Y}}=\mathrm{a}+\mathrm{bX} \rightarrow$ kecerdasan emosinal siswa $=53,330+$ 0,28 bahasa Indonesia. Artinya koefisien regresi kecerdasan emosinal siswa sebesar 0,28 menyatakan bahwa setiap peningkatan kecerdasan emosinal sebesar $100 \%$ akan meningkatkan pmebelajaran bahasa Indonesia sebesar $28 \%$.

\section{f. Uji Hipotesis Komparatif.}

Pengujian ini perlu dilakukan dengan dasar bahwa terdapatnya hasil belajar bahasa Indonesia yang diinstrumentasikan melalui pretes dan postes. Setelah melalui pendeskripsian dan uji persyaratan normalitas maka analisis dilakukan dengan menggunakan pengolahan SPSS 23.0 dengan uji $t$ - paired sample test. Dan berikut hasil pengolahannya

Tabel 3.9. Paired Samples Test

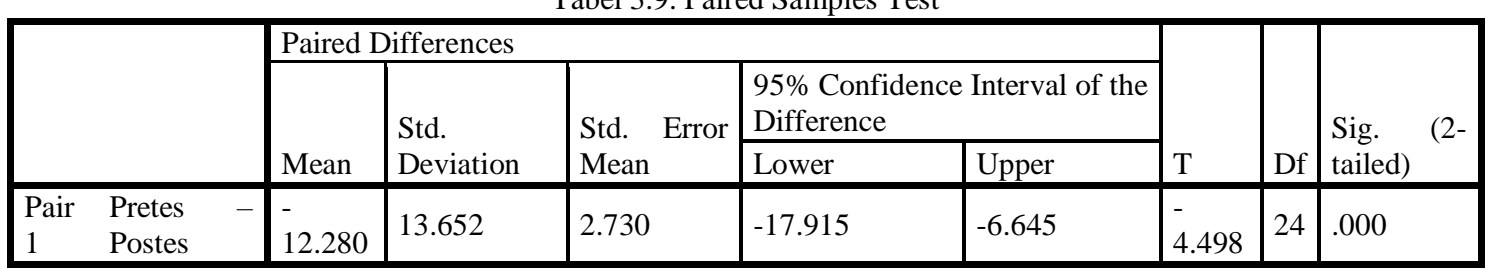

Berdasarkan tabel 3.8 diperoleh sig lebih kecil dari pada $\alpha$ yaitu $0,000<0,05$. Hal ini menunjukkan bahwa hasil belajar bahasa Indonesia oleh siswa mengalami perubahan yang signifikan (berarti). Dengan demikian dapat disimpulkan bahwa terdapat peningkatan hasil belajar siswa akibat pengaruh kecerdasan emosional yang distimulus kepada siswa melalui penelitian ini.

\subsection{Pembahasan Penelitian}

Hasil data yang di peroleh di lapangan selama melakukan proses pendekatan kecerdasan emsional yang di lakukan oleh peneliti kepada kelas yang telah di berkan pendekatan kecerdasan emosional di peroleh hasil dimana siswa lebih aktif dan lebih kritis dalam merespon pembelajaran yang diajarkan di kelas seperti hal nya pengertian kecerdasan emosional yang di tulis Daniel golamen dalam bukunya mengenai kecerdasan emosional yaitu Kecerdasan emosional secara nyata memberikan pengaruh yang cukup berarti dalam membina moral dan sikap peserta didik, dan tentunya juga akan memberikan dampak kepada kemampuan setiap peserta didik dalam menerima pembelajaran.

Keterampilan dasar dalam menerapkan kecerdasan emosional tidak dapat dimiliki secara tiba-tiba, dibutuhkan proses dalam mempelajarinya serta lingkungan yang tepat untuk membentuk kecerdasan emosional yang optimal. Berbeda hal nya dengan kelas kelas yang tidak di berikan pendekatan kecerdasan emosional, dimana siswa nya hanya sebagian yang aktif dan tidak lebih aktif dari kelas yang berikan pendekatan kecerdasan emosional.

Dengan menerapkan pendekatan kecerdasan emosional dari hasil pengamatan peneliti yaitu di peroleh perbandingan yaitu kelas yang di berikan pendekatan kercerdasan emosioal maka dapat di kategorikan sangat baik dalam merespon dan aktif dalam pembelaajran. Hal ini dikarenakan pendekatan kecerdasan emosional ini mmeberikan dampak yang positif terhadap diri siswa dimana siswa menjadi termotivasi da lebih bersemangat dalam belajar.

Sedangkan pada kelas yang tidak di berikan pendekatan kecerdasan emosional dapat di katakan kurang memuaskan hasil yang di dapatkan karena masih di sebagain siswa yang memiliki motivas dan semangat belajar di kelas sehingga membuat kurangnya hasil pembelajaran bahasa indonesia yang di dapatkan. Jadi penerapan kecerdasan emosional dalam kelas sangat cocok di lakukan oleh setiap pengajar dalam mengajar di kelas di bandingkan tidak di lakukan pendekatan. Karena akan memacu semanagat siswa dalam belajar dan mendapatkan hasil belajar yang sangat baik jika setiap guru menerapkan pendekatan kecerdasan emosional.

a. Hasil tes belajar siswa

Hasil belajar yang diperoleh dalam penelitian ini merupakan evaluasi yang dilakukan oleh peneliti melalui instrumen tes dengan materi pelajaran yang sudah dibelajarkan sebelumnya. Tujuan dilakukan tes adalah untuk memahami kemampuan belajar siswa sekaligus menggunakan data ini untuk kemudian dikaitkan terhadap hasil analisis kecerdasan emosional siswa.

Dimana peneliti memberikan kan soal mengenai pembelajaran yang telah diajarkan sebelumnya dan sesudah dapatkan hasil yang memenuhi KKM. Tampak bahwa rata-rata (mean) pretes berbeda dengan mean postes dimana rentang niai 80-100 pada pretest 2(8\%) sedangkan postes 4(16\%) pada rentang nilai 60-79 pada pretest $13(52 \%)$ sedangkan pada postes $21(84 \%)$ rentang nilai $40-59$ pada pretest $10(40 \%)$ dan pada postes $0(0 \%)$,hasil tes ini juga menggambarkan bahwa data pretes lebih bervariasi daripada data postes dengan penyimpangan data terbesar terdapat juga pada data pretes. diketahui bahwa masing-masing nilai terendah dan tertinggi untuk setiap populasi data yaitu 40/80 dan 65/88. 
setelah di lakukan teadment menganai kecerdasan emosional peneliti memberikan soal kecerdasan emosional dan angket kepada siswa untuk mengukur tes kecerdasan emosioanl setiap siswa dan di dapatkan hasil sebagai berikut hasil tes dan angket kecerdasan emosional menunjukkan rata-rata tes yaitu 112,32 sedangkan hasil angket diperoleh kecederungan pilihan pada sangat setuju dan setuju dengan masing masing persentase sebesar 32\% dan 31\%. Dengan merujuk acuan kriteria penilaian yang telah dirumuskan maka untuk hasil tes kecerdasan emosional memiliki kecerdasan emosional yang baik karena memiliki ratarata di atas 100 (ukuran rata-rata kecerdasan emosional). Selanjutnya untuk hasil angket dapat juga diketahui bahwa pilihan siswa cederung pada pilihan setuju dan sangat setuju.

Untuk melihat ada atau tidaknya perbedaan yang signifikan terhadap hasilbelajar pada kelas sebelum dan sesudah di berikan pendekatan kecerdasan emosional maka dapat di laukan pengujian hipotesis. Dalam penelitian ini uji hopotesis di lakukan dua bentuk uji hipotesis yaitu hipotesis asosiatif dan hipotesis komparatif. Dan hasil yang diperolh dalam uji hipotesis asosiatif adalah sebagai berikut Berdasarkan pengolahan SPSS maka harga sig. lebih kecil daripada harga $\alpha$ yaitu $0,001<0,05$. Dengan demikian diterima $\mathrm{H}_{\mathrm{a}}$ bahwa terdapat pengaruh yang signifikan kecerdasan emosional terhadap pembelajaran Bahasa Indonesia. Dan untuk mengetahui besarnya sumbangan efektif kecerdasan emosional dalam pembelajaran Bahasa Indonesia dapat digunakan hasil pengolahan SPSS melalui koefesien determinasi $\left(\mathrm{R}^{2}\right)$.

Melalui hasil pengolahan pada tabel 3.6. diperoleh $\mathrm{R}^{2}$ sebesar 0,408 . Hal ini mengartikan bahwa kecerdasan emosional siswamemberikan sumbangan efektif sebesar 40,8\% berpengaruh terhadap pembelajaran Bahasa Indonesia siswa. Sedangkan sisanya 59,2\% dipengaruhi variabel lainnya yang tidak dianalisis dalam penelitian ini. Dan juga hasil uji hipoesis yang di peroleh dengan uji hopitesis komparatif adalah sebagai berikut dengan uji $t$-paired sample testdiperoleh sig lebih kecil dari pada $\alpha$ yaitu $0,000<$ 0,05. Hal ini menunjukkan bahwa hasil belajar bahasa Indonesia oleh siswa mengalami perubahan yang signifikan (berarti).

Dengan demikian dapat disimpulkan bahwa terdapat peningkatan hasil belajar siswa akibat pengaruh kecerdasan emosional yang distimulus kepada siswa melalui penelitian ini. Sehingga penerapan pendekatan kecerdasan emosional dalam proses belajar mengajar akan lebih efektif jika diterapkan oleh guru.

\section{KESIMPULAN}

Berdasarkan hasil penelitian dan pembahasan, maka dapat ditarik kesimpulan dengan adanya kecerdasan emosional yang diterapkan bagi siswa kelas VIII SMP Talitakum Medan ketika siswa belajar Bahasa Indonesia Siswa bisamemotivasi diri akan mampu mempertahankan semangat hidup, untuk selalu optimisterhadap sesuatu hal. Dalam penelitian ini uji hopotesis di lakukan dua bentuk uji hipotesis yaitu hipotesis asosiatif dan hipotesis komparatif. Dan hasil yang diperolh dalam uji hipotesis asosiatif adalah sebagai berikut Berdasarkan pengolahan SPSS maka harga sig. lebih kecil daripada harga $\alpha$ yaitu 0,001< 0,05. Dengan demikian diterima $\mathrm{H}_{\mathrm{a}}$ bahwa terdapat pengaruh yang signifikan kecerdasan emosional terhadap pembelajaran Bahasa Indonesia. Dan untuk mengetahui besarnya sumbangan efektif kecerdasan emosional dalam pembelajaran Bahasa Indonesia dapat digunakan hasil pengolahan SPSS melalui koefesien determinasi $\left(\mathrm{R}^{2}\right)$. Melalui hasil pengolahan pada tabel 3.6. diperoleh $\mathrm{R}^{2}$ sebesar 0,408 . Hal ini mengartikan bahwa kecerdasan emosional siswamemberikan sumbangan efektif sebesar 40,8\% berpengaruh terhadap pembelajaran Bahasa Indonesia siswa. Sedangkan sisanya 59,2\% dipengaruhi variabel lainnya yang tidak dianalisis dalam penelitian ini. Dan juga hasil uji hipoesis yang di peroleh dengan uji hopitesis komparatif adalah sebagai berikut dengan uji $t$-paired sample testdiperoleh sig lebih kecil dari pada $\alpha$ yaitu $0,000<0,05$. Hal ini menunjukkan bahwa hasil belajar bahasa Indonesia oleh siswa mengalami perubahan yang signifikan, terdapat peningkatan hasil belajar siswa akibat pengaruh kecerdasan emosional yang distimulus kepada siswa melalui penelitian ini. Sehingga penerapan pendekatan kecerdasan emosional dalam proses belajar mengajar akan lebih efektif jika diterapkan oleh guru.

\section{Saran}

Mengingat pendekatan kecerdasan emosionalmemberikan pengaruh yang positif terhadap hasil belajar siswa, maka diharapkan kepada guru untuk dapat menerapkan pendekatan kecerdasan emosional pada proses belajar mengajar di kelasuntuk meningkatkan ketuntasan hasil belajar siswa dan kepada pihak lain utuk melakukan penelitian yang sama padamateri lain sebagai perbandingan dari hasil penelitian ini.

\section{DAFTAR PUSTAKA}

Goleman,D (1996). Emotional intelligence,jakarta: PT Gramedia Pustaka Utama.

Goleman,D (1998).kecerdasan emosional,jakarta : PT Gramedia Pustaka Utama.

Goleman,D (1996). Kecerdasan emosional ,jakarta: PT Gramedia Pustaka Utama.

Segal, jeanne. Meningkatkan kecerdasan emosional, program untuk memperkuat naluri dan emosi anda,citra aksara. 
Shapiro ,lawrence E (1997). Mengajarkan emotional intelligence pada anak ,jakarta: PT Gramedia Pustaka Utama.

http://repositori.uin-alauddin.ac.id/4360/1/Sri\%20Sumiyati\%20Ahmad\%20Putri.pdf di unduh pada 23-319/20:23

http://etheses.uin-malang.ac.id/2771/1/10410137.pdf di unduh pada 24-3-2019/16:10

file:///C:/Users/WIN\%208/Downloads/1836-4234-1-PB.pdf di unduh pada 27-5-2019/20:18

http://repository.uksw.edu/bitstream/123456789/7792/1/PROS Faderina\%20K Pengaruh\%20Kecerdasan \%20Emosional_fulltext.pdf diunduh pada 2-5-2019/12:4

https://repository.usd.ac.id/9923/2/031334048_Full.pdf diunduh pada 3-5-2019:20:12

http://repository.uksw.edu/bitstream/123456789/7792/1/PROS_Faderina\%20K_Pengaruh\%20Kecerdasan \%20Emosional_fulltext.pdf diunduh pada 10-5-2019/11:2 